\title{
Antimicrobial Effect of Honey from the Arabian Gulf Region against Bacterial Isolates from Pus and Wound Swabs
}

\author{
Nihar Dash ${ }^{1}$, Debadatta Panigrahi², Mansour Al-Zarouni ${ }^{3}$ \\ ${ }^{1}$ Department of Clinical Sciences, College of Medicine, University of Sharjah, Sharjah, United Arab Emirates \\ ${ }^{2}$ College of Medicine, RAK Medical and Health Sciences University, Ras al-Khaimah, United Arab Emirates \\ ${ }^{3}$ EML Diagnostics, Sharjah, United Arab Emirates \\ Email: *ndash@sharjah.ac.ae
}

How to cite this paper: Dash, N., Panigrahi, D. and Al-Zarouni, M. (2016) Antimicrobial Effect of Honey from the Arabian Gulf Region against Bacterial Isolates from Pus and Wound Swabs. Advances in Microbiology, 6, 745-752.

http://dx.doi.org/10.4236/aim.2016.610073

Received: June 13, 2016

Accepted: August 23, 2016

Published: August 26, 2016

Copyright (๑) 2016 by authors and Scientific Research Publishing Inc. This work is licensed under the Creative Commons Attribution International License (CC BY 4.0).

http://creativecommons.org/licenses/by/4.0/

\begin{abstract}
Of the many beneficial effects attributed to honey, its antimicrobial properties have drawn considerable interest. Five types of natural honey originating from three countries but available in the local markets in UAE were randomly selected. The antibacterial activity of the honey types was tested against bacterial reference strains as well as 21 bacterial isolates obtained from pus and wound swabs from patients. All the five types of honey showed antibacterial activity, however, there were differences in the antibacterial efficacy of the different honey types. All the strains of Staphylococcus aureus (reference, clinical and methicillin-resistant) exhibited better susceptibilities contrast to the gram-negative isolates including Escherichia coli and Pseudomonas aeruginosa when tested against all different honey types. The findings from this study indicate that the antibacterial activity of locally available honey varies depending on their provenance. Further work is needed to identify factors which determine the antimicrobial efficacy of these different honey types. Their antibacterial activity can be explored for the treatment of wound infections in patients.
\end{abstract}

\section{Keywords}

Honey, Provenance, Antibacterial Activity, UAE

\section{Introduction}

Of the many beneficial effects attributed honey, its antimicrobial properties remain perhaps the most important and widely studied [1]. The osmotic effect of the high sugar content of honey contributes to this antimicrobial effect, although experimental data 
indicate that other constituents of honey such as the mild acidity, presence of hydrogen peroxide and production of inhibins also play a role in the antibacterial activity of honey [2]. In recent years, there has been renewed interest in the use of honey for various therapeutic purposes, including treatment of infected wounds [2]-[5]. Current data now indicate that the beneficial effect of honey varies markedly depending on the floral source and this has stimulated the search for different types of honey with antibacterial activity [6]-[9]. Although various in-vitro and in-vivo studies have been carried out to assess the antimicrobial properties of honey from different parts of the world, there are only a few reports on honey originating from the Arabian Gulf region and the Indian subcontinent [10]-[12]. Thus this study was designed to study the antimicrobial activity of five types of natural honey available in the local markets of UAE against bacteria isolates including reference and pathogenic strains obtained from pus and wound swabs of patients.

\section{Methods}

\subsection{Honey Samples}

Five types of natural honey originating from three countries (UAE, Yemen and Pakis$\tan$ ) but locally available in the UAE market were randomly selected for the study. All honey samples were transferred into plastic sterile containers and given unique study labels. Table 1 shows the different types of honey, their provenance and assigned study labels. For the antibacterial assays, the honey samples were used undiluted and at $75 \%$ and $50 \%$ dilutions (wt/vol).

\subsection{Bacterial Isolates}

The bacterial isolates included in this study were three reference strains ( $S$. aureus ATCC 29213, E. coli ATCC 25922 and P. aeruginosa ATCC 27853) and 21 clinical isolates obtained from pus and wound swabs from patients in the local hospital (Table 2). All bacterial strains were cultured and identified using standard laboratory methods. All MRSA isolates were confirmed by BD PHOENIX automated microbiology system (Becton Dickinson, USA) included in the PMIC/ID test panel for gram-positive bacteria of the BD PHOENIX system according to the manufacturer's instructions. For the antibacterial assessment assay, each microorganism was suspended in Muller Hinton Broth and diluted to achieve $0.5 \mathrm{Mc}$ Farland turbidity. Culture of serial dilutions of this

Table 1. Provenance and unique study labels of the five different honey studied.

\begin{tabular}{cccc}
\hline Type of honey & Country of origin & Name of honey & Label \\
\hline Natural & Yemen & Sadr (Zizyphys lotus $)$ & A \\
Natural & United Arab Emirates & Sadr (Zizyphys lotus $)$ & B \\
Natural & Pakistan & Sadr (Zizyphys lotus $)$ & C \\
Natural & Yemen & Samur (Acacia tortilis $)$ & D \\
Natural & United Arab Emirates & Samur (Acacia tortilis $)$ & E \\
\hline
\end{tabular}


Table 2. Bacterial isolates and their clinical sources.

\begin{tabular}{|c|c|}
\hline Isolates name & Clinical source \\
\hline 1. S. aureus & Wound swab \\
\hline 2. S. aureus & Wound swab \\
\hline 3. S. aureus & Pus \\
\hline 4. $S$. aureus & Wound swab \\
\hline 5. $S$. aureus & Pus \\
\hline 1. MRSA & Wound swab \\
\hline 2. MRSA & Wound swab \\
\hline 3. MRSA & Wound swab \\
\hline 4. MRSA & Pus \\
\hline 1. E. coli & Wound swab \\
\hline 2. E. coli & Wound swab \\
\hline 3. E. coli & Wound swab \\
\hline 4. E. coli & Pus \\
\hline 5. E. coli & Pus swab \\
\hline 6. E. coli & Wound swab \\
\hline 1. $P$. aeruginosa & Wound swab \\
\hline 2. $P$. aeruginosa & Wound swab \\
\hline 3. $P$. aeruginosa & Pus swab \\
\hline 4. $P$. aeruginosa & Pus \\
\hline 5. $P$. aeruginosa & Wound swab \\
\hline 6. $P$. aeruginosa & Pus \\
\hline
\end{tabular}

bacterial suspension on Muller Hinton agar plates, followed by colony counts confirmed that this was equivalent to $10^{5}-10^{6}$ colony forming unit per $\mathrm{ml}(\mathrm{CFU} / \mathrm{ml})$.

\subsection{Assessment of Antibacterial Activity}

The previously described agar well diffusion assay was used as a susceptibility screening test [6] [13]. Briefly, $4 \mathrm{ml}$ of bacterial suspension containing $10^{6} \mathrm{CFU} / \mathrm{ml}$ was inoculated onto the surface of Muller Hinton agar plates and allowed to dry. Using a sterile cork-borer, $5 \mathrm{~mm}$ diameter wells were cut from the agar and $50 \mu \mathrm{l}$ of the appropriate honey concentration was delivered into the well. The plates were incubated for 18 hours at $37^{\circ} \mathrm{C}$. Antibacterial activity of the honey was evaluated by measuring the zone of inhibition (ZI) against the test microorganism at the end of the incubation period. All experiments were carried out in triplicate.

\section{Results}

\subsection{Activity of Honey against Reference Bacteria Isolates}

Honey E consistently gave zones of inhibition against all three reference strains at the three concentrations (Table 3) and was found to be the most effective one. The least 
Table 3. Zone of inhibition of reference strains of bacteria when tested against concentrations of different honey types.

\begin{tabular}{|c|c|c|c|c|c|c|c|c|c|}
\hline \multirow{4}{*}{$\begin{array}{l}\text { Label of } \\
\text { honey }\end{array}$} & \multicolumn{9}{|c|}{ Zone of inhibition (mm) } \\
\hline & \multicolumn{3}{|c|}{ S. aureus ATCC 29213} & \multicolumn{3}{|c|}{ E. coli ATCC 25922} & \multicolumn{3}{|c|}{ P. aeruginosa ATCC 27453} \\
\hline & \multicolumn{9}{|c|}{ Concentration of honey } \\
\hline & $100 \%$ & $75 \%$ & $50 \%$ & $100 \%$ & $75 \%$ & $50 \%$ & $100 \%$ & $75 \%$ & $50 \%$ \\
\hline A & 16 & 13 & 13 & 10 & - & - & 10 & - & - \\
\hline B & 19 & 15 & - & 12 & 10 & - & 11 & 10 & - \\
\hline $\mathrm{C}$ & 17 & 16 & 15 & - & - & - & 12 & 10 & - \\
\hline $\mathrm{D}$ & 11 & - & - & - & - & - & 10 & - & - \\
\hline $\mathrm{E}$ & 23 & 19 & 18 & 15 & 11 & 10 & 17 & 14 & 12 \\
\hline
\end{tabular}

“-”: No zone of inhibition.

effective honey D showed the least antibacterial activity as it only inhibited bacterial growth of two isolates at $100 \%$ concentration with ZI of $10-11 \mathrm{~mm}$. S. aureus ATCC 29213 was the bacterial isolate which showed the greatest susceptibility as its growth was inhibited by all concentrations of three out of the five honey types tested. E. coli ATCC 25922 showed the least susceptibility as it was completely unaffected by two of the five honey types tested (Table 3). In addition the ZI range of $10-15 \mathrm{~mm}$ was the lowest compared to $11-23 \mathrm{~mm}$ for $S$. aureus ATCC 29213 and $10-17 \mathrm{~mm}$ for $P$. aeruginosa ATCC 27453.

\subsection{Activity of Honey against Clinical Isolates from Wound Swabs}

Twenty one clinical isolates obtained from pus and wound swabs of patients in the UAE were tested. This comprised of nine $S$. aureus isolates (four of which were MRSA), six E. coli and six P. aeruginosa isolates (Table 2). All the honey types tested showed good activity against the $S$. aureus isolates. The least effective honey was honey $\mathrm{D}$ which only inhibited four of the five isolates at $100 \%$ concentration. At $100 \%$ concentration, honey E showed the best ZI (18 - $24 \mathrm{~mm}$ ) compared to a range of $12-15 \mathrm{~mm}$ seen with other isolates (Tables 4-7). There was a trend of higher antibacterial effect of honey against the MRSA isolates as the range of ZI seen with these isolates were higher compared to those seen with the non-MRSA isolates (Table 4 and Table 5).

The antibacterial activity of all honey types against the $E$. coli isolates was poor. Four of the five honey types (A-D) failed to exhibit any antibacterial effect against one of the isolates (E. coli 1$)$ and another isolate (E. coli 3 ) was only inhibited at $100 \%$ concentration. The highest ZI $(15 \mathrm{~mm})$ was seen at $100 \%$ honey E against one isolate (E. coli 2 ) (Table 6).

Honey E showed the best antibacterial activity against the Pseudomonas isolates as it inhibited three of the six isolates at all concentrations (Table 7). Four honey types (A-D) failed to inhibit $P$. aeruginosa 3 isolate at all concentrations. At all concentrations, the ZI seen with honey E was consistently higher than that seen with the other honey types. The results are comparable with the reference bacterial isolates. 
Table 4. Zone of inhibition ( $\mathrm{mm}$ ) of $S$. aureus (5 isolates) against concentrations of different types of honey.

\begin{tabular}{|c|c|c|c|c|c|c|c|c|c|c|c|c|c|c|c|}
\hline \multicolumn{16}{|c|}{ Zone of Inhibition (mm) } \\
\hline \multirow{3}{*}{$\begin{array}{c}\text { Bacteria isolates } \\
\text { Type of } \\
\text { Honey }\end{array}$} & \multicolumn{3}{|c|}{ S. aureus 1} & \multicolumn{3}{|c|}{$S$. aureus 2} & \multicolumn{3}{|c|}{$S$. aureus 3} & \multicolumn{3}{|c|}{$S$. aureus 4} & \multicolumn{3}{|c|}{$S$. aureus 5} \\
\hline & \multicolumn{15}{|c|}{ Concentration of honey } \\
\hline & $100 \%$ & $75 \%$ & $50 \%$ & $100 \%$ & $75 \%$ & $50 \%$ & $100 \%$ & $75 \%$ & $50 \%$ & $100 \%$ & $75 \%$ & $50 \%$ & $100 \%$ & $75 \%$ & $50 \%$ \\
\hline A & 14 & - & - & 20 & 16 & 12 & 18 & 15 & 10 & 18 & 14 & 10 & 12 & - & - \\
\hline B & 17 & 17 & 14 & 16 & 15 & 12 & 17 & 16 & 13 & 18 & 16 & 14 & 15 & 13 & 12 \\
\hline $\mathrm{C}$ & 16 & 15 & 13 & 16 & 14 & 12 & 18 & 16 & 14 & 18 & 16 & 15 & 15 & 13 & 12 \\
\hline $\mathrm{D}$ & 11 & - & - & 12 & - & - & 12 & - & - & 13 & 10 & - & 10 & - & - \\
\hline $\mathbf{E}$ & 20 & 18 & 15 & 18 & 16 & 14 & 20 & 17 & 15 & 22 & 20 & 18 & 18 & 16 & 14 \\
\hline
\end{tabular}

“-”: No Zone of inhibition.

Table 5. Zone of inhibition of MRSA (4) against concentrations of different types of honey.

\begin{tabular}{|c|c|c|c|c|c|c|c|c|c|c|c|c|}
\hline \multicolumn{13}{|c|}{ Zone of Inhibition (mm) } \\
\hline \multirow{3}{*}{$\begin{array}{c}\text { Bacteria isolates } \\
\text { Type of } \\
\text { Honey }\end{array}$} & \multicolumn{3}{|c|}{$M R S A 1$} & \multicolumn{3}{|c|}{$M R S A 2$} & \multicolumn{3}{|c|}{$M R S A 3$} & \multicolumn{3}{|c|}{$M R S A 4$} \\
\hline & \multicolumn{12}{|c|}{ Concentration of honey } \\
\hline & $100 \%$ & $75 \%$ & $50 \%$ & $100 \%$ & $75 \%$ & $50 \%$ & $100 \%$ & $75 \%$ & $50 \%$ & $100 \%$ & $75 \%$ & $50 \%$ \\
\hline A & 20 & 14 & 12 & 18 & 15 & 11 & 15 & 11 & 10 & 18 & 14 & 12 \\
\hline B & 21 & 18 & 17 & 19 & 17 & 15 & 18 & 45 & 13 & 20 & 17 & 14 \\
\hline $\mathrm{C}$ & 19 & 17 & 15 & 18 & 16 & 15 & 19 & 16 & 14 & 20 & 16 & 14 \\
\hline $\mathrm{D}$ & 11 & - & - & 11 & 10 & - & 10 & - & - & 10 & 10 & - \\
\hline $\mathrm{E}$ & 23 & 19 & 17 & 22 & 19 & 17 & 22 & 18 & 15 & 24 & 20 & 18 \\
\hline
\end{tabular}

“-”: No Zone of inhibition.

Table 6. Zone of inhibition of E. coli (6) isolates against concentrations of different types of honey.

\begin{tabular}{|c|c|c|c|c|c|c|c|c|c|c|c|c|c|c|c|c|c|c|}
\hline \multicolumn{19}{|c|}{ Zone of Inhibition (mm) } \\
\hline $\begin{array}{l}\text { Bacteria } \\
\text { isolates }\end{array}$ & \multicolumn{3}{|c|}{ E. coli 1} & \multicolumn{3}{|c|}{ E. coli 2} & \multicolumn{3}{|c|}{ E. coli 3} & \multicolumn{3}{|c|}{ E. coli 4} & \multicolumn{3}{|c|}{ E. coli 5} & \multicolumn{3}{|c|}{ E. coli 6} \\
\hline \multirow{2}{*}{$\begin{array}{l}\text { Type of } \\
\text { Honey }\end{array}$} & \multicolumn{18}{|c|}{ Concentration of honey } \\
\hline & $100 \%$ & $75 \%$ & $50 \%$ & $100 \%$ & $75 \%$ & $50 \%$ & $100 \%$ & $75 \%$ & $50 \%$ & $100 \%$ & $75 \%$ & $50 \%$ & $100 \%$ & $675 \%$ & $50 \%$ & $100 \%$ & $\% 75 \%$ & $50 \%$ \\
\hline A & - & - & - & 10 & 9 & - & 10 & - & - & - & - & - & - & - & - & 10 & 8 & - \\
\hline B & - & - & - & 12 & 10 & - & 10 & - & - & 10 & 8 & - & 8 & - & - & 8 & 6 & - \\
\hline $\mathrm{C}$ & - & - & - & 13 & 10 & - & 11 & - & - & 10 & 6 & - & 6 & - & - & 8 & 6 & - \\
\hline $\mathrm{D}$ & - & - & - & 12 & - & - & 11 & - & - & 8 & - & - & 8 & - & - & 6 & - & - \\
\hline $\mathrm{E}$ & 14 & 11 & - & 15 & 12 & 10 & 15 & 10 & - & 12 & 10 & - & 14 & 12 & - & 14 & 10 & - \\
\hline
\end{tabular}

“-”: No Zone of inhibition. 
Table 7. Zone of inhibition of $P$. aeruginosa (6) isolates against concentrations of different types of honey.

\begin{tabular}{|c|c|c|c|c|c|c|c|c|c|c|c|c|c|c|c|c|c|c|}
\hline \multicolumn{19}{|c|}{ Zone of Inhibition (mm) } \\
\hline \multirow{2}{*}{$\begin{array}{l}\text { Bacteria } \\
\text { isolates }\end{array}$} & \multirow{2}{*}{\multicolumn{3}{|c|}{$\begin{array}{c}P . \text { aeruginosa } \\
1\end{array}$}} & \multirow{2}{*}{\multicolumn{3}{|c|}{$\begin{array}{c}P . \text { aeruginosa } \\
2\end{array}$}} & \multirow{2}{*}{\multicolumn{3}{|c|}{$\begin{array}{c}P . \text { aeruginosa } \\
3\end{array}$}} & \multirow{2}{*}{\multicolumn{3}{|c|}{$\begin{array}{c}P . \text { aeruginosa } \\
4\end{array}$}} & \multirow{2}{*}{\multicolumn{3}{|c|}{$\begin{array}{c}P . \text { aeruginosa } \\
5\end{array}$}} & \multirow{2}{*}{\multicolumn{3}{|c|}{$\begin{array}{c}P . \text { aeruginosa } \\
6\end{array}$}} \\
\hline & & & & & & & & & & & & & & & & & & \\
\hline \multirow{2}{*}{$\begin{array}{l}\text { Type of } \\
\text { Honey }\end{array}$} & \multicolumn{18}{|c|}{ Concentration of honey } \\
\hline & $100 \%$ & $\% 75 \%$ & $50 \% 1$ & $100 \%$ & \% 75\% & $50 \%$ & $100 \%$ & $675 \%$ & $50 \%$ & $100 \%$ & $675 \%$ & $50 \%$ & $100 \%$ & $75 \%$ & $50 \% 1$ & $100 \%$ & $675 \%$ & $50 \%$ \\
\hline A & 11 & - & - & 11 & 10 & - & - & - & - & 10 & - & - & 8 & - & - & 8 & - & - \\
\hline B & 12 & 11 & - & 12 & 11 & 6 & - & - & - & 10 & 8 & - & 8 & 6 & - & 8 & - & - \\
\hline $\mathrm{C}$ & 12 & 10 & - & 14 & 11 & 8 & - & - & - & 12 & 8 & - & 8 & 5 & - & 10 & 8 & - \\
\hline $\mathrm{D}$ & 12 & 10 & - & 11 & 8 & - & - & - & - & 12 & 6 & - & 10 & 6 & - & 12 & 6 & - \\
\hline $\mathrm{E}$ & 15 & 13 & 11 & 18 & 14 & 12 & 12 & - & - & 14 & 10 & 6 & 12 & 8 & - & 12 & 6 & - \\
\hline
\end{tabular}

“-”: No Zone of inhibition.

\section{Discussion}

The variation in the antibacterial properties of honey has been linked with its provenance [6] [8] [13] [14]. Indeed, the composition and therapeutic effects of honey tend to differ based on the floral source as well as geographical origin [15]. In this study, we have examined pure natural honey from two floral sources namely Zizyphys Lotus and Acacia tortilis obtained from different geographical locations within our region. The findings confirmed differences in the antibacterial efficacy of the different honey types with honey E (Acacia tortilis; UAE origin) showing the best activity against the three pathogens tested. Honey D which is also Acacia tortilis but of different geographical origin (Yemen) demonstrated poor antibacterial activity. Indeed, honey A, B \& C ( $Z i$ zyphys Lotus) of different geographical origins had better activity compared Honey D. It has been suggested that a combination of factors act in consonance to determine the antibacterial efficacy of any honey type. Factors such as sugar content, high viscosity, mild acidity and hydrogen peroxide release are important in determining the antibacterial activity of honey. It may also differ depending on floral and/ or geographical provenance [13] [14]. The diversity in the antibacterial activity of the honey types tested in this study appears to be supportive of this notion.

In terms of the antibacterial activity of the honeys on the different bacterial strains tested, $S$. aureus was the most inhibited bacterial strain while $E$. coli was the least susceptible. Both the reference strains and clinical isolates of these bacteria showed good susceptibility to all honey types tested. In recent years, treatment of MRSA infections has become a major challenge facing clinicians. As MRSA isolates are important etiological agents in skin and wound infections, it is therefore of clinical significance that all MRSA isolates showed increased susceptibility to the honey types tested. These findings are in keeping with other reported work and indicate that the use of honey may represent an effective and less expensive approach for local wound cleaning of $S$. aureus infected wounds [8] [9]. In contrast, the overall trend was for lower susceptibil- 
ity to the Gram-negative bacteria (E. coli \& P. aeruginosa) tested. However although $E$. coli was resistant to most of the honey types tested, $P$. aeruginosa was relatively more susceptible with the exception of $P$. aeruginosa 3 . $P$. aeruginosa is usually found in skin wounds particularly those related to burns and represents an important cause of nosocomial infection in burn patients. Hence the relatively good antibacterial effect of honey on these bacteria is of clinical significance and indicates the need for further work to identify other locally available honey with significant antibacterial activity.

There were potential limitations to this study. First, the number of clinical isolates tested against the honey samples was limited. Second, the antimicrobial test method and the choice of test organism(s), varies between publications and may be difficult to compare with other published results.

\section{Conclusion}

The findings from this study indicate that the use of locally available honey for the treatment of wound infections appears promising. However, differences in antibacterial activity exist among available honey depending on their provenance. Further chemical analysis is needed to identify the factors which determine the antimicrobial efficacy of different honey types.

\section{Conflict of Interest}

Nothing to declare.

\section{References}

[1] Al-Waili, N.S., Salom, K., Butler, G. and Al Ghamdi, A.A. (2011) Honey and Microbial Infections: A Review Supporting the Use of Honey for Microbial Control. Journal of Medicinal Food, 14, 1079-1096. http://dx.doi.org/10.1089/jmf.2010.0161

[2] Israili, Z.H. (2014) Antimicrobial Properties of Honey. American Journal of Therapeutics, 4, 302-323.

[3] Mandal, M.D. and Mandal, S. (2011) Honey: Its Medicinal Property and Antibacterial Activity. Asian Pacific Journal of Tropical Biomedicine, 1, 154-160. http://dx.doi.org/10.1016/S2221-1691(11)60016-6

[4] Al-Waili, N., Salom, K. and Al-Ghamdi, A.A. (2011) Honey for Wound Healing, Ulcers, and Burns; Data Supporting Its Use in Clinical Practice. Scientific World Journal, 11, 766787. http://dx.doi.org/10.1100/tsw.2011.78

[5] Dunford, C. (2005) The Use of Honey-Derived Dressings to Promote Effective Wound Management. Professional Nurse, 20, 35-38.

[6] Basualdo, C., Sgroy, V., Finola, M.S. and Marioli, J.M. (2007) Comparison of the Antibacterial Activity of Honey from Different Provenance against Bacteria Usually Isolated from Skin Wounds. Veterinary Microbiology, 124, 375-381.

http://dx.doi.org/10.1016/j.vetmic.2007.04.039

[7] Brudzynski, K. (2006) Effect of Hydrogen Peroxide on Antibacterial Activities of Canadian Honeys. Canadian Journal of Microbiology, 52, 1228-1237. http://dx.doi.org/10.1139/w06-086

[8] Lusby, P.E., Coombes, A.L. and Wilkinson, J.M. (2005) Bactericidal Activity of Different 
Honeys against Pathogenic Bacteria. Archives of Medical Research, 36, 464-467. http://dx.doi.org/10.1016/j.arcmed.2005.03.038

[9] Zainol, M.I., Mohd Yusoff, K. and Mohd Yusoff, M.Y. (2013) Antibacterial Activity of Selected Malaysian Honey. BMC Complementary and Alternative Medicine, 13, 129-135. http://dx.doi.org/10.1186/1472-6882-13-129

[10] Al-Jabri, A.A., Al-Hosni, S.A., Nzeako, B.C., Al-Mahrooqi, Z.H. and Nsanze, H. (2005) Antibacterial Activity of Omani Honey Alone and in Combination with Gentamicin. Saudi Medical Journal, 26, 767-771.

[11] Al-Jabri, A.A., Nzeako, B., Al Mahrooqi, Z., Al Naqdy, A. and Nsanze, H. (2003) In Vitro Antibacterial Activity of Omani and African Honey. British Journal of Biomedical Science, 60, 1-4.

[12] Al-Waili, N.S., Akmal, M., Al-Waili, F.S., Saloom, K.Y. and Ali, A. (2005) The Antimicrobial Potential of Honey from United Arab Emirates on Some Microbial Isolates. Medical Science Monitor, 11, 433-438.

[13] Küçük, M., Kolayli, S., Karaoğlu, S., Ulusoy, E., Cemalettin, B. and Candan, F. (2007) Biological Activities and Chemical Composition of Three Honeys of Different Types from Anatolia. Food Chemistry, 100, 526-534. http://dx.doi.org/10.1016/j.foodchem.2005.10.010

[14] Miorin, P.L., Levy Junior, N.C., Custodio, A.R., Bretz, W.A. and Marcucci, M.C. (2003) Antibacterial Activity of Honey and Propolis from Apis mellifera and Tetragonisca angustula against Staphylococcus aureus. Journal of Applied Microbiology, 95, 913-920. http://dx.doi.org/10.1046/j.1365-2672.2003.02050.x

[15] Mercan, N., Guvensen, A., Celik, A. and Katircioglu, H. (2007) Antimicrobial Activity and Pollen Composition of Honey Samples Collected from Different Provinces in Turkey. Natural Product Research, 21, 187-195. http://dx.doi.org/10.1080/14786410600906277

Submit or recommend next manuscript to SCIRP and we will provide best service for you:

Accepting pre-submission inquiries through Email, Facebook, LinkedIn, Twitter, etc. A wide selection of journals (inclusive of 9 subjects, more than 200 journals)

Providing 24-hour high-quality service

User-friendly online submission system

Fair and swift peer-review system

Efficient typesetting and proofreading procedure

Display of the result of downloads and visits, as well as the number of cited articles

Maximum dissemination of your research work

Submit your manuscript at: http://papersubmission.scirp.org/ 